\title{
The Implications of the Odwira Festival for Christianity and Christian Mission in Okuapeman
}

\begin{abstract}
Since 1826, the Akuapem people of Ghana have annually celebrated the festival known as the Okuapehene Dwira (the Odwira of the paramount chief of Akuapem), Odwira for short. The paper examines the spiritual significance of the festival for the people. It considers what an Okuapeni (a person who comes from Akuapem) who converts to Christ may need to do to enable him/her enjoy life in Christ, and why. The paper gives a brief description of the festival after establishing its history. It follows this by arguing that Odwira is a covenant renewing festival which places all Akuapemfo (Akuapem people) under a covenant with the Odosu (a regalia). The paper then discusses two theological views on the effect of such covenants on people who convert to Christianity. The paper concludes with what Christian ministers must ensure that Akuapem converts do to give them the assurance that in Christ, they are liberated from the covenant. The paper is based on observations, recorded interviews with natives of Akuapem chiefs, students, opinion leaders and "ordinary" members of the society, as well as responses to questionnaires administered to natives of Akropong living in Akropong itself, Sakumono and Lashibi in the Greater Accra Region. Works of theologians like Ogbu Kalu, Opoku Onyinah, and some others have also been used. The finding of this paper is that effective Christian ministry in Akuapem must include "deliverance". This will ensure that converts who believe that the covenant with Odosu must be verbally renounced at conversion to Christ, have the assurance of being freed from the covenant. This paper contributes to Missiology and Ministry by adding to the on-going debate on spiritual covenants and their effect on Christian conversion.
\end{abstract}

Keywords: Okuapehene Dwira, Festival, Conversion, Deliverance, Covenant and Mission.

\section{INTRODUCTION}

Festivals are celebrated by communities to mark occasions like harvests, and to commemorate war victories, ancestors, and deities. They may also be celebrated to renew religious covenants between communities and deities. Where festivals are celebrated to renew existing covenants, every celebration, brings about the renewal of the covenant with the entire community. The Okuapehene Dwira is a traditional festival celebrated by Akuapemfo (Akuapem people) of Ghana. The author of this paper is of the view that this festival is one of the covenant-renewing festivals. The paper therefore establishes this fact and then considers two theological views on what the implications are for Christian ministry among the Akuapemfo. The question that this paper seeks to answer is whether Akuapemfo must personally, in the name of Jesus, renounce the covenant with Odosu as well as the curses that come with it when they are converted to the Christian faith or not. The paper begins by giving a history of the festival, showing how Akuapemfo came to start celebrating it.

\section{History of Okuapehene Dwira}

The Akuapem state is in Ghana in West Africa. It is situated between longitude $0^{\circ} 15 \mathrm{~W}-0^{\circ} 00$ and latitude $5^{\circ} 45-6^{\circ} 00$ N. Once every year the Okuapehene (the paramount chief of the Akuapem state) leads his people to celebrate the festival known as Okuapehene Dwira in Akropong, the capital of the Akuapem state. There are over seventeen (17) towns 
forming the state. These include Berekuso, Aburi, Ahwerease, Obosomase, Tutu, Mampong, Amanokrom, Mamfe, Larteh Ahenease, Larteh Kubease, Akropong, Abiriw, Dawu, Awukugua, Adukrom and Apirede. Tradition has it that the people began celebrating the festival in 1826. According to history, a native of Jbosomase, a town in Akuapem, captured the regalia known as Odosu from the Asante warriors during a war. This war was fought by a coalition of Akuapem, Akim, Fante, Ga, Adangme, Akwamu the British and the Danes against Asante at Katamanso, a town on the Accra Plains, near Dodowa. He captured the regalia along with an elderly woman who was attending to it, and brought them to Akropong. ${ }^{2}$ This is stated in the account of the war by M. A. Kwamena-Poh. ${ }^{3}$ Kwamena-Poh does not call what was captured Odosu; he states however that the head of the late Governor, Sir Charles Macarthy which Asante had taken in 1824, fell into the hands of Nana Addo Dankwa I, the Okuapehene. Akuapemfo to whom the author spoke, said that the Odosu is made up of the skulls of great kings defeated by the Asante in their various wars. They mentioned specifically the skull of Sir Charles Macarthy.

The story continues that the woman captured with the regalia, told the Okuapehene that for Akuapem to benefit from the presence of the Odosu in their state, they would have to celebrate the Odwira annually. Further information on the history of the celebration given by Nana Addo Birinkorang, Apâsâmakahene (chief spokesman of the chief), says that the Akuapem warriors who fought in the Katamanso war returned to Akuapem on August 11, $1826 .{ }^{4}$ On August 16, 1826, the Jman (state) led by the Okuapehene, held spiritual consultations on the Odosu under the Mpeni tree in Akropong. On August 25, 1826, they performed rites to purify the Jman after the war. That same day, during the purification ceremonies, they held consultations and took the decision to make Odwira an annual Akuapem Festival. ${ }^{5}$

\section{The Celebration of Okuapehene Dwira ${ }^{6}$}

The Okuapehene Dwira is celebrated in September or October each year ${ }^{7}$ with the Okuapehene being the main officiant. Since the Okuapehene represents the entire Okuapeman, the living, the dead, and those who have not yet been born, every Okuapeni is covered in what he does. Noel Smith gives the time for the celebration of the festival as August or September. However, since 2000 it has not been celebrated in August. ${ }^{8}$ It is often said that the festival lasts for a period of about two weeks with most activities taking place in the first week. It is not clear though how long the festival lasts. Some people say it lasts for a week; others say two weeks while still others say three weeks. Preparations for the celebration of the festival starts with a performance of rites by the Okuapehene known as Adaebutuw (literally, turning the sleeping place upside-down) to declare a period of six weeks of silence. During this period, it is forbidden for anyone to make noise, so all forms of noise making are forbidden. There is no drumming, no mourning, no clapping, and so on. The reason for this period, according to the Banmuhene (custodian of the royal mausoleum) is that Nananom Nsamanfo (the ancestors) take their rest. ${ }^{9}$ To ensure that they have a good rest, the town is kept quiet and peaceful. During this period of silence, the eating of new yams is also forbidden.

The first day of the festival is always a Monday. On this day, a delegation is sent by the Okuapehene to go and clear the path that leads from Akropong to Amanprobi, the town in which the first Akyem settlers lived after the war of liberation from the Akwamu people. It lies a few kilometres to the right side of the road that leads from Mamfe to Koforidua. This is where banmu, the royal mausoleum is. They clear the path so that Nananom Nsamanfo, (the royal ancestors) may travel safely to join in the celebration. On this trip, the delegation also informs Nananom Nsamanfo of their intention to return the next day to escort them to Akropong. They present items that will enable Nananom Nsamanfo to get prepared to come into the town the next day. These items include sponges for bathing and for cleaning the mouth, lime, cocoyam, palm-nuts, and roasted corn-on-the-cob When the delegation returns to Akropong that day, they inform the Okuapehene that they have discharged their duty.

On Tuesday, which is a Dapaa, ${ }^{10}$ (literally, good or lucky day), the people clean all utensils and things in the palace and homes. They get food items and all that will be needed the next day ready so the people can observe the

\footnotetext{
Interviews with Nana Addo Dankwa III, Okuapehene and Nana Kwame Afari Bampo II, Banmuhene in their respective palaces on October 12, 2004 and October 22, 2004 respectively.

Kwamena-Poh, "History", David Brokensha, Akuapem Handbook, (Accra-Tema: Ghana Publishing Corporation, 1972$), 45$.

4 Nana Addo Birikorang, "Akuapem Odwira - Adaebutuw Festival”, Akuapem Odwira and Adae Butuw Festivals - Odwira Souvenir Brochure, 1998, 2. Nana Addo Birinkorang was the Apâsâmakahene of Akropong.

Ibid.

This section is based on the observations of the festival by the author over six consecutive years.

Noel Smith, "Religious Beliefs", in David Brokensha, Akwapim Handbook, 116.

This statement is being made from observations by the author from 2000 to 2009.

He made this known to me in an interview with him in his palace in Akropong on October 22, 2004.

10 The Akan follow the adaduanan calendar. This is a forty-day calendar. Twice every adaduanan, the chief takes offerings of food and drinks to the royal ancestors by visiting the room in the palace where the "Black Stools" are kept. These days are called Adae. One of the Adae in the adaduanan cycle is the Adaekâse and the other, the Adaeketewa. Every Adae is a holiday. The day preceding an Adae is a Dapaa.
} 
holiday appropriately. In the ahenfie (palace), the "white stools" 11 are brought into the forecourt and washed by the Nkonguasoafo (the stool bearers). This same day, the ban that was placed on the eating of sde (yam) and the making of noise during the Adaebutuw is lifted. A rite is performed by the people of a special house known as the Krubii house to launch the new sde. This day is known as the Kwabena Ayensu Benada, in honour of the man who, according to tradition, discovered sde. As part of the rite to lift the ban on the eating of the sde, tubers of the crop are paraded through the principal street of the town and the young men scramble for pieces of it. ${ }^{12}$ On this same day, the delegation that went to clear the path to Amanprobi the previous day, goes back to escort Nananom Nsamanfo to the town. Soon after the delegation returns and is received in the palace, the ban on the making of noise is lifted and life returns to normal.

The next day, Wednesday is supposed to be an Adae ${ }^{13}$ day, Adaekâse (big Adae). It is however not observed as such as it falls in the week for the celebration of Odwira. It is rather observed as the day for mourning the dead. The dress code for this day is therefore black, red, or brown, the colours that people wear when in mourning. People mourn their dead and if a member of a family died during the Adaebutuw period, arrangements are made for the burial and funeral. In the afternoon, the Okuapehene goes to the different houses in which there are nkongua tuntum (black stools) to mourn with them. Nkongua tuntum are heirlooms which represent the royal ancestors. They are made of wood and blackened by smearing a mixture of eggs and soot collected from the kitchen on them. ${ }^{14}$ There are several opinions on why the stools are blackened, ${ }^{15}$ but they will not be discussed in this paper. Late that night, under cover of darkness, the nkongua tuntum of the state are taken from ahenfie to the Adami River for ritual cleansing.

Thursday marks the beginning of the new afe (year). It is a day of feasting. The people prepare sumptuous meals and enjoy with family and friends. In the afternoon, food is sent to Nsorem, the place that marks the second place that the Okuapehene and his people settled when they joined the Guans, to feed Nananom Nsamanfo. In the night of this day, the rite known as sesadompe amanne (literally, the custom of collecting bones) is performed. In this rite, the Odosu is paraded through the town to cleanse it of all mmusu (evil).

On Friday, a grand durbar is held by the Okuapehene and his people. All the Divisional Chiefs are expected to be present. People from all walks of life are invited to this function. It starts at about eleven O'clock in the morning. The Okuapehene and the Divisional Chiefs, as well as some other ahenfo (chiefs) who are qualified to ride in palanquins are paraded through the town. Then they all gather at Mpeniase, under the canopy of the Mpeni tree which stands in front of the palace of the Okuapehene. The durbar starts with prayers and then speeches are made by a government official and the Okuapehene. In his speech, the Okuapehene may give account of developmental tasks they may have done in the state. He may also bring up things that need to be done, as well as talk about the plans that he and his elders are making to meet certain needs of the people. If there are any amenities that they are expecting the national government to help them acquire, he may also make his request through the government official present. This government official also makes known the plans of the government for the nation as a whole and Okuapeman in particular.

On Saturday, social activities like the crowning of Miss Odwira (a beauty pageant), Odwira Dance, quiz competitions, and football matches are held. A lot of socialising goes on this day. Then a church service dubbed Odwira Thanksgiving Service is held on Sunday. The following week, nothing much happens until Friday, a day known as Fofie, when the Okuapehene eats with his akrafo (souls) after they have performed rituals to cleanse themselves. The Queen mother also cooks and serves her people. In the afternoon, as part of the closing ceremony, the Okuapehene sits in state and various functionaries come and bless him. Later, the Ayokohene (leader of the members of the Oyoko clan in Akropong) comes with his team to perform a rite to close the celebration.

\section{Odwira, a covenant renewing festival}

The author of this paper is of the view that the Okuapehene Dwira is a covenant renewing festival, and in this section, gives the reasons for this view. It is therefore important to gain an understanding of what a covenant is at this point. The English word "covenant" stands for a mutual agreement between two or more parties with each binding itself to fulfil certain obligations. ${ }^{16}$ In the Hebrew Bible, the word Beriyth is used to refer to a covenant. The Strong's Concordance defines this word as a "compact." ${ }^{17}$ It refers to a treaty, a pledge or an agreement. In the New Testament, the Greek word used for covenant is Diatheke and it means "a disposition, arrangement, testament or will." A covenant can therefore be said to be "an eternal agreement between parties who commit themselves to each other for mutual benefit. Usually it is

\footnotetext{
11 The "white stools" are the stools which the past chiefs used while they were alive. They are not blackened. Presently, there are six of them in the palace of the Okuapehene.

Some young ladies also may join in the scramble for pieces of the yam.

An Adae is a day on which the Jmanhene who is the Okuapehene makes offerings to his ancestors.

Peter Sarpong, The Sacred Stools of the Akan, (Accra-Tema: Ghana Publishing Corp, 1971), 42.

Ibid.,37 - 38 .

Kevin Conner and Ken Malmin, The Covenants, (Portland, Oregon: City Bible Publishing, 1997) 1

7 James Strong, Strong's Concordance (A Concise Dictionary of the Words in the Hebrew Bible with their Renderings in the King James Version), (Nashville: Abingdon Press, 1986), 30.
} 
in the form of a vow promising blessings when kept and curses when broken." ${ }^{18}$ Generally, the purpose of a covenant is to provide a binding sense of commitment to a relationship. ${ }^{19}$

According to tradition, when the captured $O d o s u$ was brought to Akropong, an elderly woman who was captured with it told the Okuapehene that while they had the Odosu in their possession, they would have to celebrate Odwira in order to benefit from it. Following this, Okuapeman started celebrating Odwira. In the celebration of Odwira, the people do what they were told to do if they would benefit from the presence of Odosu in their midst. Odwira is therefore celebrated in fulfilment of the requirement for those who possess the Odosu and want to benefit from it. Leaders of Okuapeman know that celebrating Odwira is required of the people who have the Odosu in their possession. In response to a question about what would happen if Okuapeman failed to celebrate Odwira, the Okuapehene said that nothing would happen but then added that it would never happen that Odwira would not be celebrated. He said that if for any reason an elaborate Odwira could not be celebrated, they would perform a rite known as "Jtô pete" (sprinkling of mashed yam). According to him they must always commemorate the event because of the presence of the Odosu. ${ }^{20}$ The Banmuhene also affirmed this. ${ }^{21}$ Both of them could however not tell what would happen if the festival was not celebrated. This is because, as they said, there has not been a time in the history of the kingdom, since the Odwira was instituted, when it has not been celebrated. History confirms that no matter what, Akuapemfo celebrate Odwira. One year during the reign of Nana Kwame Fori II, the District Commissioner asked the people not to celebrate Odwira but the Okuapehene said that it must be celebrated. That year there was ôtô pete. This was between 1951 and $1952 .{ }^{22}$ Also, in 1987 there was so much trouble in Okuapeman, and everyone thought Odwira would not be celebrated, but it was celebrated. ${ }^{23}$ In all these instances the amanhene (paramount chiefs) at the time said that they must by all means feed Nananom Nsamanfo and must therefore celebrate Odwira. However, Nananom Nsamanfo are fed twice in every adaduanan (forty-day cycle) on the days known as Adae throughout the year. They do not need Odwira to be fed. This strengthens the view that their feeding was given as a reason just to cover up the real reason for the celebration. The insistence on the celebration of the festival by the amanhene gives the impression that the celebration of Odwira is an obligation. To say that something is an obligation is to say that that thing must be done no matter what. The celebration is compulsory. Okuapeman celebrates Odwira no matter what, in fulfilment of the agreement that exists between Odosu and Okuapeman. When Okuapeman gathered at Mpeniase on August 25, 1826, they agreed to celebrate Odwira annually as they had been told to do if they were going to keep the Odosu. The celebration is therefore in keeping with the agreement which is a covenant. It is this festival that ensures that Okuapeman continues to benefit from the presence of the Odosu in the state. It is therefore a covenant renewing festival. A look at some other festival may make this point clearer.

The Aboakyer festival is celebrated by the people of Winneba, a town in the Central Region of Ghana. The town was founded in AD 1530 by Effutus who came from Amanforo-Ogua. They were descendants of the Guan and the Mo from Bono-Manso, the former capital of the Bono kingdom. They were led in their search for a place to settle by the second twin son, Simpa, of their first king, Bondziebi Gyartey. These migrants defeated the people of the town known as Apa and took Winneba together with their most important deity, Sekum Apa from them. They renamed the deity Penkye Otu. Some historical traditions however say that Penkye Otu was the deity which the migrants brought with them. These traditions claim that it assisted them in all their travels. Whichever way, the fact is that Penkye Otu is the principal deity of the Effutu and is seen as the custodian and guardian of the state.

Every year, Penkye Otu is given a sacrifice to enable it to perform its duties as the custodian of the state with powers to foretell the future. The annual sacrifice is meant to say to the deity, "we are still with you." This is done as part of the Aboakyer festival. Akanfo (the Akan) believe that the vital force of a deity loses strength if it is not rejuvenated from time to time. When the sacrifice is made, usually during the festivals, the ôkra (soul) of the deity joins that of Onyame (God) and then returns to earth with renewed and revived strength. ${ }^{24}$ The significance of the festival is therefore a rejuvenation of the deity. Many activities form part of the celebration and many people may mistake these activities for the reason behind the celebration, but the true reason is the giving of new strength to the deity, an act which shows that the covenant between them and the deity still exists.

In the same way, Odwira is a celebration which shows that Okuapeman accepts the Odosu as that which protects them. On Thursday morning of the Odwira week, the Okuapehene makes a sacrifice of an oguan kôkôô (literally, a red sheep) to the Odosu. Research has revealed that what is called oguan kôkôo is a dog. This is usually not mentioned in

18 See John B. Ghartey, Marriage Means More: Pragmatic Positive Principles for Building a Happy Home, (Accra: Living Word Foundation, 2009), 13.

19 Conner and Malmin, Covenants, 3.

20 Interview with Nana Addo Dankwa III on October 12, 2004.

21 Interview with Banmuhene on October 22, 2004.

22 Michelle Gilbert, “Aesthetic Strategies: The Politics of a Royal Ritual, Africa: Journal of the Internal African Institute, 64/1, (1994), $109,111$.

23 Ibid.

24 Karikari Akyempo, Aboakyer:Deer Hunt Festival of the Effutus, (Accra: Anowuo Educational Publishers, undated), 10 - 12. 
accounts on how the festival is celebrated. The Twi expression for what the sacrificial animal is used for is "due". In the Mfantse Nkasafua na Kasambirenkyi Nkyerâase (Dictionary of Mfantse Words and Idioms) ${ }^{25}$, the meaning of due is given as "to smear with blood as purification or sacrifice". It has to do with empowering, giving it life. This sacrifice is the climax of the festival. All other activities are by-products. Odwira is a festival for the renewing and revitalising of the Odosu. It is difficult to tell whether the strength of the Odosu to perform depends on the celebration of the festival or that the Odosu would only perform its duty if the people celebrated Odwira. It could be both. The Odosu is given the strength and the authority to serve Okuapeman through the celebration of Odwira.

There is a contract, a covenant between Okuapeman and the Odosu, and this is the reason why Odwira is celebrated. E. V. Asihene's comment on the Aboakyer festival makes this point clearer. He says that the exclusive Aboakyer festival is meant to honour a covenant with Penkye Otu their "god protector." 26 In Akan religion, when a person adopts an obbosom (a deity), it is done through a kind of contract which is a covenant. The person seeking to become a devotee agrees to terms dictated by the ôbosom and the ôbosom also agrees to protect and help the devotee. If it is a suman (amulet), it is the same. There will be requirements and prohibitions which constitute a contract. M. J. Field makes a similar comment on the acquisition of help from a wôn, the Ga equivalent of ôbosom. According to her, when a person has observed the proper ceremonies in becoming the owner of a wôn, the $w \hat{o} n$ will act for him. ${ }^{27}$ The stories of the beginning of Odwira in Okuapeman as told by elders of the state, give the impression that the Odosu, by the sheer fact that it was captured by Akuapemfo and brought to Akropong, became the protector of Okuapeman. However, as related by the late Nana Addo Birikorang, spiritual consultations were held and after that the people adopted the festival. Even though he did not explicitly say what the consultations were about, it is likely that it had to do with the rites that gave Okuapeman claim to the protection of the Odosu; these rites were, as occur in Akan religion, covenantal rites, rites that defined the relationship between Okuapeman and the Odosu.

Normally, in a covenant or contract, the one who initiates the covenant makes it available and the one receiving it responds by accepting the terms. ${ }^{28}$ This is exactly what happened with the Odosu. The relationship between the Odosu and Akuapemfo shows that there is a covenant between them. It was the Odosu through its Asante attendant that spelt out the terms of the covenant in saying that Odwira would have to be celebrated annually. In the Odwira festival, Akuapemfo keep their side of the covenant and renew it. This has been going on since 1826.

\section{Odwira, a covenant renewing festival: its implications}

In the view of Pentecostal-Charismatics, covenants between spiritual entities and communities bring God's curse upon the community. From the side of the covenant itself, failure to do what is required leads to the one who has broken the covenant suffering negative consequences, when they turn to Jesus Christ in conversion. One proponent of this view is Ogbu U. Kalu. What Kalu says in his writing on festivals meant for the renewal of covenants among the Igbo, has implications for interpreting the Odwira Festival and its influence on the lives of Akuapemfo. He observes that in their encounter with their environment, the Igbo have covenanted with thousands of deities. Through these covenants, the Igbo receive all sorts of spiritual help from the deities. He explains that in these covenants, the deities dictate the terms and prescribe the taboos and fees. This is done through a ritual agent. He goes on to say that festival cycles are used to renew covenantal relationships. ${ }^{29}$

Akuapemfo, like the Igbo, see the world as one in which there is the need for protection from demonic and other negative forces. Due to this, the people often make covenants with spiritual beings and powers for protection, one of which is that between them and the Odosu; they believe that in addition to the Supreme Being, they need the support of other spirits in the environment to protect them from malevolent spirits, and to give them victory over their enemies, especially during war. This is what the priest to whom Rattray spoke was talking about when he said that they cannot look up to Onyankopôn alone for protection. ${ }^{30}$ The people, in spite of their knowing that Onyankopôn is the Supreme Being, still feel that they need the support of other ahonhom (spirits). According to Kalu, to save themselves from demonic and other evil forces, the people usually consolidate, and abide in and with, what they see as saving spirits through covenants. These covenants are enforced periodically. ${ }^{31}$ Odwira, as has already been noted, is a festival for enforcing the covenant between the Odosu and Okuapeman. The Odosu therefore plays a very important role in the whole celebration. People rightly say that Odwira is celebrated for the Odosu. It is the Odosu that demands the whole "purification" rite. It is not as though the people desire purification which they obtain with the help of the Odosu.

\footnotetext{
J. Yedu Bannerman et al, Mfantse Nkasafua na Kasambirenkyi Nkyerâase, (Tema: CEFIKS, 2011), p. 264.

E. V. Asihene, Apoo Festival, (Tema: Ghana Publishing Corporation, 1980), 11.

M. J. Field, Religion and Medicine of the Ga People, (Accra: Presbyterian Book Depot, 1961), 111.

Kevin Conner and Ken Malmin, The Covenants, (Portland, Oregon: City Bible Publishing, 1997) 9.

Ogbu U. Kalu, The Embattled Gods: Christianization of Igboland 1841-1991, (Lagos: Minaj Publishers, 1996), 48.

R. S. Rattray, Ashanti, (Oxford: Claredon Press, 1927).

Kalu, The Embattled Gods, 33.
} 
Odwira is not just about cleansing as the name suggests, and as some of the leaders of Okuapeman have indicated; ${ }^{32}$ it is mainly for the renewal of a covenant. The rites are performed to ensure that the Odosu continues to protect Okuapeman. "Odwira without Odosu is not Odwira," ${ }^{33}$ as it then is not a renewal of the covenant. The festival that renews the covenant also gives the benefit of cleansing and purification to the people. It is therefore not just purification for a better relationship with the benevolent ahonhom but mainly a ceremony to ensure that the covenant between the Odosu and Okuapeman is kept intact.

Odwira signifies the covenant between Akuapemfo and the Odosu as well as the renewal of that covenant. This stand is strengthened by the fact that the celebration of the festival has continued in Okuapeman even though Christianity has taken strong roots among the people. The amanhene of Akuapem who have been associated with the Church have not, in their reigns, been able to prevent the celebration of the festival. Each of them has followed tradition and celebrated Odwira. Nana Addo Dankwa III said that in his reign of thirty-five years, ${ }^{34}$ he has celebrated Odwira every year. Oseadeâys Addo Dankwa III is himself a professed Christian; yet he has faithfully celebrated the festival throughout his reign. This means that he made the sacrifice of the oguan kôkôo to the Odosu every year on behalf of Okuapeman. He was the one who said that it would never be the case that Odwira would not be celebrated in a certain year.

Writing on the Odwira Festival, Gilbert says that it is believed that if it is not celebrated, there will be disaster, famine and pestilence. ${ }^{35}$ The way Gilbert puts it is interesting for it brings up the fact that non-celebration will definitely have negative consequences on the state. She does not say that non-celebration could lead to the occurrence of disaster, famine and pestilence, but that it will lead to these troubles. Before the Odosu was brought into Okuapeman, the people did not celebrate Odwira but these calamities did not occur. However, after the capture of the Odosu, and the demand for the celebration of Odwira, a non-celebration of Odwira would leave the people in an evil situation, the consequence of not keeping their side of the bargain. Akuapemfo choose to celebrate Odwira in order to benefit from the Odosu. Whatever is done during the celebration culminates in the pleasure of the Odosu. If after the capture of the Odosu there was no demand for the celebration of Odwira by its attendant, Akuapemfo would not have started the celebration of the festival at all. Every celebration of the festival is in line with the terms of the covenant and stands for its renewal. The continued celebration of the festival therefore keeps the covenant strong. The festival thus has implications for Okuapeman and its people. What is done physically has implications in the spiritual realm.

\section{Spiritual implications of Odwira for Okuapeman and Akuapemfo}

There are always consequences for breaking a covenant. Kalu asserts that getting out of covenants made with spirits is not a simple matter; he avers that the spirit pursues the offender through generations of his descendants. ${ }^{36}$ Would the situation be the same if a person gets out of a covenant like this one and enters into a covenant with the Lord Jesus Christ? There are two theological views on this issue. The subsequent sections discuss these views.

\section{The first theological view}

The first view is that the spirit with whom one has a covenant cannot pursue him/her when s/he gets into a covenant with Jesus Christ and becomes a Christian. A Christian is a person who has heard what God has done for humanity through Jesus Christ and has responded positively to it. When this happens, a relationship is started between the Lord Jesus Christ and that person, a relationship that makes the person a child of God. Writing about this in his prologue, John says, The true light that enlightens every man was coming into the world. He was in the world, and the world was made through him, yet the world knew him not. He came to his own home, and his own people received him not. But to all who received him, who believed in his name, he gave power to become children of God; who were born, not of blood nor of the will of the flesh nor of the will of man, but of God. ${ }^{37}$

According to John, people who received the true light, Jesus Christ, those who believed in His name, received power from Him to become God's children. Explaining this verse, F. F. Bruce writes that those who welcomed the Word, the true light, when He came into the world, were given the birth-right to every blessing and privilege which His coming had been designed to impart. Explaining further, Bruce says that a summary of the blessings and privileges is the

\footnotetext{
2 Interviews with the Banmuhene and Adumhene on October 22, 2004 and March 4, 2008 respectively.

33 This is a statement which the Banmuhene made when he was describing the Odwira being celebrated by the divisions which had seceded. Interview with him in his palace on October 22, 2004.

34 This was in 2004.

35 Gilbert, "Aesthetic Strategies: The Politics of a Royal Ritual, (99).

36 Kalu, The Embattled Gods, 47.

37 John 1: 9 - 13 (RSV).
} 
admission into the family of God. ${ }^{38}$ To receive Jesus is "to place one's faith in $[\mathrm{H}] \mathrm{im}$, to yield one's allegiance to $[\mathrm{H}]$ im"; it is to acknowledge Jesus' claims in the most practical way. To believe in the name of Jesus, is to acknowledge that His claims are true. His "name" refers to His real character or He Himself. The writer of this Gospel therefore avers that what is needed to make a person a child of God is faith in who Jesus is. Such a person according to Paul, has been rescued or transferred from the dominion, authority of darkness and brought into the kingdom of God's beloved Son. This rescue, Murray J. Harris posits, takes place at the conversion of an individual to Christ. The moment a person receives Christ, the person is transferred from the authority of darkness and brought into the kingdom of Christ. He/ she enters a covenant, the covenant mediated by Jesus Christ. "[I]n a collective and proleptic sense," the rescue or transfer took place when Jesus died. ${ }^{39}$ When an individual comes to faith in Christ, the transfer occurs for that person. The person is delivered from the authority of all other forces and brought under the authority of Christ. A Christian, no matter where he or she comes from, is adopted into the family of Abraham and is covered by the terms of the Abrahamic covenant which is made perfect by the New Covenant mediated by Christ. This New Covenant has been put into place through the blood of Christ. Christians, having been sprinkled with this blood have thus been brought into the New Covenant. There are several passages in the Bible that point to the fact that because of the death of Jesus upon the cross and His subsequent resurrection, no other spirit or force has authority over the believer.

This is the point made in the Lausanne Occasional Paper 18 (LOP 18). Under covenants that may exist between deities of the original religion and the convert to the Christian faith, the paper says that if a person breaks a covenant with any deity by becoming a Christian, the curse or penalty of breaking the covenant has fully fallen on Jesus already as He has fully paid the price of that curse. The Christian is therefore fully set free. ${ }^{40}$ No spirit from any other covenant can claim anything from this convert. One proponent of this view is Marilyn Hickey. She asserts that as soon as one repents, every curse in the person's life is removed. ${ }^{41}$ In her view, a convert does not need to specially renounce these old covenants and curses to be set free from them. The reasoning behind this point is that the covenant that Christ has brought in is better than the old one, it is more powerful. God had been in a covenant with Israel before Jesus brought in the new one. Thus, in Hebrews 8:6, the writer says that the covenant which Jesus Christ mediates is better than the first one. The new covenant therefore makes the old one obsolete, that is, the new one makes the old one no longer useful. While it may be said that these old and new covenants have to do with the Biblical covenants, God's covenants with Israel, and therefore has nothing to do with Africans and their covenants with the spirits in their world, it must also be remembered that according to Christian doctrine, God is the creator of all things, visible and invisible. ${ }^{42}$ Any covenant between any of His creatures comes under His control. If even the old covenant made by God Himself with Israel has been made obsolete by the new covenant, how can anyone say that a covenant made by a spirit with a people can withstand the new covenant? Even taking the Akan world view into consideration, and saying that the covenant made between an obosom and a person or community is not a demonic covenant but one with a honhom papa (good spirit) which is considered Onyame ba (child of Onyame) by the community or person, the covenant mediated by Jesus Christ is better as it is made by the blood of Jesus and not the blood of animals. The covenant with Jesus therefore renders it obsolete. Nobody would want to live by a second-class covenant when there is a first-class one. The two covenants may have one source, but the new covenant made in and with Christ is better than the one with the obosom. With the understanding that the ôbosom is derived from God, breaking a covenant with an ôbosom should not have any negative consequences for the convert just as moving out of the Abrahamic covenant, the old covenant, to the new covenant in Christ has no negative consequences.

The problem comes when the old covenant is with ahonhom bone, (demons, principalities and powers, forces of darkness). When the convert moves from such a covenant, there will be negative consequences, but these have already been taken care of by Jesus. Jesus Christ, in His death and resurrection, has conquered all forces of darkness, principalities and powers. Paul writes that Jesus has disarmed the principalities and powers and "made a public example of them triumphing over them in him". ${ }^{43}$ Explaining this verse, H. Dermot McDonald says it means that,

Christ the crucified is Lord; and all the hostile powers of the universe have become subjected

to him. In Christ's cross the demonic hosts of evil have met their Conqueror. ${ }^{44}$

Every hostile power in the world is subject to Jesus. All forces that may be behind a covenant with a deity are subject to Jesus. H. M. Carson puts it this way, "God, in Christ, stripped from the powers of evil their hold over the lives of

\footnotetext{
38 F. F. Bruce, The Gospel of John, Introduction, Exposition and Notes, (Grand Rapids, Michigan: William B Eerdmans Publishing Company, 1983), 38.

39 Murray J. Harris, Colossians and Philemon, (Grand Rapids, Michigan: William Eerdmans Publishing Company, 1991$), 35$.

40 “Christian Witness to People of African Traditional Religions," (LOP 18) - Lausanne Movement.

41 Marilyn Hickey, Breaking the Generation Curse, (Denver: Marilyn Hickey’s Ministry, 1988), 88.

42 Shirley Guthrie, Christian Doctrine, (Louisville, Kentucky: Westminster/John Knox Press, 1994), 162.

43 Colossians 2:15 (RSV).

44 H. Dermot McDonald, Commentary on Colossians and Philemon, (Waco, Texas: Word Books, 1980), 87.
} 
men." ${ }^{45}$ When a convert enters the new covenant mediated by Christ, the old one, whether with ahonhom papa or ahonhom bone, ceases to operate; the covenant ends, and the new one begins to operate. In this sense therefore, there is no need for any further religious rites to be performed to free this new Christian from the consequences of breaking the old covenant.

In the case of Akuapemfo and the covenant with the Odosu, when an Okuapeni converts to Christ and stops pandering to the spirit of the Odosu, he/she will not have to fear the consequences of breaking away as whatever the consequences may be have been taken up by the Lord Jesus Christ. The evil forces that may want to attack have been defeated by the Lord Jesus already.

For this school, the old covenant may continue to operate where conversion is not genuine, and evil forces may attack the said convert. It is possible that some people may profess Christianity without being fully committed to the faith. Jesus Himself said that it is not everyone who calls Him Lord who belongs to His kingdom. ${ }^{46}$ By saying this, Jesus drew attention to the fact that being committed to a profession of faith in Him is important to belonging to Him. Commitment to Him is seen in the willingness to do the Father's will. This is when Christ is the one who occupies the throne of a person's heart and not the person himself or herself. Commenting on Jesus' statement, Douglas R. A. Hare observes that in these words, Jesus shows that true "righteousness consists not in possessing the teachings of Jesus, but in acting upon them." ${ }^{" 47}$ A Christian is one who is fully committed to Jesus Christ. One cannot have a partial stand with Christ and a partial stand with another deity and call himself or herself a Christian. In Exodus 20:5, God describes Himself as a jealous God". He desires our total commitment. When a person is not totally committed to his or her profession as a Christian, even a verbal renunciation of an old covenant will not work. The fact that people belong to a Christian congregation does not automatically make them Christians, not even their baptism. A Christian must be committed to Christ.

In his paper on the Churches in Akuapem, Noel Smith ends by saying that when the Gospel was preached among Akuapemfo, they took it to their hearts but in doing so they added it to the totality of the spiritual resources they already possessed. ${ }^{48}$ This means that many of them accepted the Gospel but also held on to their old faith. Such people did not break up with the old faith and its covenants, they did not truly convert from it to the new one. If this is the case, then there are many Akuapemfo who may be seen as Christians but who are not, and who therefore will still have the old covenant operating in their lives. Such people will have trouble with the Odosu making demands on them. One is either a Christian or not. It is not possible to be both a Christian and a "pagan". This seems to be the story of many Africans who convert to Christianity. Thus, commenting on Christianity among the Asante, K. A. Busia describes it as a thin veneer. ${ }^{49}$ Explaining what he means by this, Busia says that the Asante Christian most probably still holds on to the world view which has for generations dominated Asante thought; that the world is ruled by Onyankopon, the allwise, all-powerful Creator of all things, but He works in the world through the abosom, spirits who are His children. ${ }^{50}$ Many Asante people therefore do not turn completely to Jesus Christ even when they make a profession of faith in Him. When people fully turn to Christ at conversion, as should be the case, they enter fully into the new covenant which surpasses all other covenants. All other covenants are therefore cancelled.

\section{The second theological view}

Birgit Meyer in her work on the Ewe of Ghana, tells the story of a woman who was excommunicated from the church by a man named Mallet. ${ }^{51}$ According to the story, after this woman converted to Christianity, she fell ill and could not be cured by any orthodox medicine. She was later informed that her uncle's "fetish" was angry with her and would make sure that she remained ill if she continued to be a Christian; she would not enjoy good health. She returned to her 'uncle's fetish and was cured. She even became a $\operatorname{tr} \ddot{Y} s i$ (a priestess in Ewe Religion). ${ }^{52}$ Andrew F. Walls also tells the following story from Uganda as it was told by "a scholarly missionary of great insight, later an English bishop."

A married woman, a communicant member of the Anglican Church, who was childless, was suddenly seized by the muzimu of the prince Luyidde, son of Kabaka Mulando, whose shrine stands on a hill not far from her village. From her body, which was stiff and numb, two

\footnotetext{
45 H. M. Carson, The Epistles of Paul to the Colossians and Philemon, (Leicester, England: Inter-Varsity Press, 1984$), 71$

46 Matthew 7: 21.

47 Douglas R. A. Hare, Interpretation: A Bible Commentary for Teaching and Preaching, Matthew, (Louisville, Kentucky: Westminster John Knox Press, 1993), 83.

48 Noel Smith, "The Churches", in David Brokensha (Ed.) Akwapim Handbook, 68.

49 K. A. Busia, "The Ashanti," in Daryll Forde, African Worlds: Studies in the Cosmological Ideas and Social Values of African Peoples, (London: Oxford University Press, 1954,1970), 208.

50 Ibid.

51 Birgit Meyer, Translating the Devil: Religion and Modernity among the Ewe in Ghana, (Edinburgh: Edinburgh University Press, 1999), 104.

52 Ibid.
} 
voices spoke, one repeating, "I am Luyidde," and her own saying, "I am a Christian; I cannot go." For days the psychosis continued, no one seemed able to help her, and eventually, her brothers and her husband, also a communicant, agreed that nothing could save her but to let her go. She is now living at the shrine on the hill, separated from her husband because she belongs to Luyidde. Once in a while she is possessed [okusamira] and speaks with his voice, but otherwise she is quite normal, regularly attends church, and is still a communicant..$^{53}$

These real-life stories call for a look into the effects of spiritual covenants on states and the individuals in the state. One would expect that as argued by the first school of thought, once a person becomes converted to the Christian faith, such covenants would cease to operate in the person's life. This does not seem to be the case as seen from the stories told by both Meyer and Walls cited above, and as Kalu points out. Kalu gives two examples of such happenings. First, he tells of the case of a family which is the custodian priest of a deity. He says that all present and future members of this family are linked inexorably to serve the deity through libations and rituals. If a member of this family decides to move away from this deity and not pander to it anymore because $\mathrm{s} / \mathrm{he}$ has become a Christian or for whatever reason, the deity will continue to make demands of the person. The spirits will be angry and negatively affect his/her life. They may cause afflictions in the person's life or they may hinder the progress of his/her career. They may cause a character flaw or a moral offence to be in the family, like proneness to sexual immorality, stealing, unstable character and so on. This may become entrenched and recur in the family. Unless the ancestral covenant is broken, the hindrances, the character flaw or moral offences will continue to cause distress even when a person from the family becomes a Christian. The person may not have entered the covenant him/herself but because s/he is a member of the family, $\mathrm{s} / \mathrm{he}$ is part of the covenant. ${ }^{54}$ The spirits may react by showing their anger towards this person and negatively affect the person by causing all kinds of afflictions to come upon him/her. Kalu further intimates that unless the covenant is renounced, this person will continue to experience the consequences of not keeping faith.

If this is so, then it raises an issue of whether a covenant with Christ may exist with other covenants in a person's life or not. Can a Christian be in the new covenant and still live under the old covenant? This second school of thought says "yes." Even where conversion is genuine, existing covenants and curses must be consciously renounced and broken. The view of this school is that for a Christian to benefit from what Jesus has achieved, s/he must consciously apply the blood of Jesus to himself or herself. Usually, the situation has been compared to Israel's journey from Egypt to Canaan. When the Israelites left Egypt, they wondered about in the wilderness for forty years. Though they were out of Egypt, they could not enjoy the full blessing of being in Canaan. The proponents of this view say that experience shows that a genuine Christian may suffer the consequences of an old covenant or live under its curse until the person claims the deliverance that Jesus has won for him or her. Francis MacNutt gives examples of such situations in his book Deliverance from Evil Spirits. Proponents of this view include Derek Prince, Kenneth McAll, and Kalu, as well as some others like Frank and Ida Hammond who wrote the book Pigs in the Parlour. ${ }^{55}$ Going by this view would mean that in a case like that of Okuapeman, when an Okuapeni converts to the Christian faith, s/he must verbally renounce his/her association with the covenant that Okuapeman has with the Odosu. S/he must also verbally remove all the curses that go with breaking God's first commandment, as well as the negative consequences that follow breaking the covenant with the Odosu. It must all be done in the name of Jesus.

The examples given by Meyer and Walls, together with those cited by Hans Kasdorf ${ }^{56}$ and several others, make it difficult not to believe that there is the need for covenants and curses to be renounced and removed verbally when an Okuapeni becomes a Christian. In his Christian Conversion in Context, Kasdorf tells the story of Wei, a sorcerer who became a Christian. According to the story, demons continued to appear to him in his dreams until the church went and held a service in his house. It was then that the dreams stopped. ${ }^{57}$ The story does not say whether there was a verbal renouncing of the old association or not, but it is interesting to note that the dreams did not stop as soon as he gave his life to Christ.

A look at what was done during baptism in the Early Church may be helpful here. During this period, believers consciously rejected the demonic realm at baptism. Andrew Daunton-Fear cites Tertullian as saying,

When we enter the water and profess the Christian faith in terms prescribed by its law, we

profess with our mouths that we have renounced the devil, his pomp and his angels. ${ }^{58}$

\footnotetext{
53 Taylor, Growth of the Church in Buganda, p. 211, in Andrew F. Walls, Cross Cultural Studies in Mission History, (Maryknoll, New York: Orbis Books, 1996), 97 - 98.

54 Kalu, The Embattled Gods, 46.

55 F. \& I. Hammond, Pigs in the Parlour: A Practical Guide to Deliverance, (Kirkwood: Impact Books, 1973).

56 Hans Kasdorf, Christian Conversion in Context, (Scottdale, Pensylvania: Herald Press, 1980).

57 Ibid $18-19$.

58 Tertullian as cited in Andrew Daunton-Fear, "Deliverance and Exorcism in the Early Church", in Kay and Parry (Eds), Exorcism and Deliverance, p. 72
} 
From what Tertullian says, in the Early Church, there was a verbal renunciation of any association with the devil and all that have to do with him at baptism. It is likely that the prayer that was said when one turned to the Lord Jesus Christ included the breaking of these old relationships. This practice seems to have ceased in the Church today. When people accept Jesus Christ, they acknowledge Him as Lord in their prayer and then they confess and repent of their sins. They also ask the Lord Jesus to come into their hearts and stay there. Perhaps, converts must be given the opportunity to confess with their mouths an ending of any covenants that may exist between them and a deity. Not only that, there must be the opportunity to nullify the consequences of breaking the covenants as well as removing the curse that comes with having been in a covenant relationship with that spirit or deity. Going by Prince's view, several Christians live under the shadow of curses because they have not verbally removed them from their lives. ${ }^{59}$ This would mean that even though Jesus Christ has redeemed the believer from the curse, until believers consciously remove the curse from themselves, they do not benefit from what Christ has done.

\section{Implications for Christian Ministry in Akuapem}

The first theological view leads us to believe that on the cross, Jesus completed His work of salvation for mankind. The victory of Christ comes immediately into effect, when one comes to faith in Christ; all the benefits of Jesus' death come into operation as soon as a person says, "Lord Jesus, I believe in you. I repent of my sins and ask for your forgiveness. I make you my Lord and Saviour. Come into my life". For this school therefore, sins are forgiven, covenants are broken, curses are removed, and Satan loses control of the believer's life immediately without the person making any verbal renunciations or removing curses in the name of Jesus.

The second view holds that even though Christ has won the victory, the battle still rages on until the Christian claims the victory won by Christ for him or her over all such things, verbally. Considering the many testimonies of Christians who until they consciously renounced such covenants and curses, lived lives that could not be considered blessed, and the evidence that in the Early Church, during baptism, converts consciously renounced such associations, it would be necessary for Akuapemfo who become Christians to consciously renounce the covenant with Odosu, and release themselves from the curse that comes from having been in that covenant, as well as the consequences that follow breaking it. Every believer has the authority to do this in the name of Jesus. This will set the minds of the believers at rest about anything that may affect their lives because of the association of Okuapeman with the Odosu. If the declaration of faith in Jesus alone is enough to set a believer free from old covenants and curses, as well as the consequences of breaking the covenant, the believer is free. If there is the need to consciously renounce them too, the believer is free. There is an Akan maxim which says, "ânam bebree nsâe nkwan" (putting plenty fish in the soup does not spoil the soup). If all covenants are broken, curses removed, and the consequences of breaking the covenant with the Odosu are dealt with by accepting Christ, a conscious verbal renunciation of the covenant and all that go with it will not spoil anything; it would rather strengthen the faith of believers that they are indeed set free. In making room for converts to consciously renounce the covenant and its consequences verbally at the time of receiving Christ as Lord of one's life, the church ensures that all doubts and fears are dealt with. Believers can then be sure that they are free indeed.

The Presbyterian Church of Ghana has a liturgy for the baptism of adults. There are portions in this liturgy where those to be baptised make certain promises and confession of faith. Questions are put to the candidates as a group and each of them is required to respond for him/herself. It is necessary to look at both the Twi and English renditions of the questions and the promises. The Twi rendition is given first and then the English.

One of the questions to which candidates are expected to answer in the affirmative, is So mopâ sâ mopa ôbonsam ne ne nnwuma nyinaa, mo kan asetra a âma mode mo ho too anyame foforo so gyaw Otumfoô Nyankopôn anaa mode mo ho too abode so gyaw Jbôadeâ no ankasa, na mosom Yesu Kristo anaa? ${ }^{60}$

Do you desire to be delivered from the dominion of the Evil One, and to leave your old life, in which you trusted in powers other than Almighty God and in which you served created things rather than the Creator, and do you desire now to enter the service of Jesus Christ? ${ }^{61}$

Looking at the question in the Akuapm Twi language, it is about whether the new believer desires to renounce the devil and all his works. To renounce, is among other things, to state publicly that one no longer has a connection with somebody because he/she disapproves of that person. In the Twi therefore, the candidates are asked if they desire to

\footnotetext{
59 Derek Prince, From Curse to Blessing: A Transcription of the Radio Program Today with Derek Prince, (Lauderdale: Derek Prince Ministries, 1986), 8, 28, 36-37.

60 Ghana Presbyterian Asafo: Asôre yâbea ne Mpae Ahorow, (Accra: Waterville Publishing House, 1987), 94.

${ }^{61}$ Presbyterian Church of Ghana, Worship Book: Ordinances, (Accra: A-Riis Company Ltd, 2010), 25
} 
state publicly the dissociation of themselves from the devil and any relationship that may be in existence between them. In the English, it has to do with desiring to be delivered from the dominion of the Evil One, a rescue from the control of the devil or from the devil's kingdom. While the first sentence in the Akuapem Twi and in the English deal with two different things, renouncing the devil and being delivered from the dominion of the devil, they both start with the statement that talks about a desire. By answering this question in the affirmative, the candidates declare their desire for a severance of relations with the devil and an entry into the service of Jesus. However, having a desire for something is not be the same as doing it. Paul writes about not being able to do what one wants to do. ${ }^{62}$ Desiring something to happen does not make the thing happen until action is taken. Instead of asking if the candidates "desire" they should rather be asked if they renounce the Evil One and leave the old life. The candidates must renounce the Evil One verbally. In the old liturgy Book, this first question was followed by a question that has been removed from the new one. Candidates were asked if they renounced certain things. The question was,

So mopa wiase yi ne emu anuonyamhunu, honam akônnô ne aniwa akônnô, afideyj, adwemmone, anibere ne onipa dada no nneyce nyinaa anaa? ${ }^{63}$

Do you renounce the glamour of this godless world, all that panders to the appetites or entices the eyes, all impurity, ill will, covetousness and all other deeds of your lower nature? ${ }^{64}$

Both the Twi and English versions of the question say about the same thing. This question has been taken out of the new Liturgy Book as it was thought to be just a repetition of the first one, but it was not. It had to do with renouncing behaviour that is unacceptable in the Christian faith, behaviour associated with serving the devil or being in his dominion. In a way, it was a question that sought to give the candidates an opportunity to renounce their association with the devil. The way the question is framed however, does not make its intention clear. After having been asked about desiring to renounce the devil, a question that leads the candidates to renounce any relationship with the devil should follow. The following question however did not do that. It rather asked if the candidates renounced "the glamour of the world..." Candidates renounced something, but it was not the relationship with the devil; they were things that the devil makes them do. It would be helpful if the question on desiring is turned into one that leads the believer to make a renunciation of the devil so that it looks like this,

Sâ mopâ ampa se mopa Jbonsam ne ne nnwuma nyinaa na mosom Otumfos Nyankopon mo nkwa nna nyinaa de a, âno de mo mpae mu nka no Onyankopon ne asafo yi anim.

If you sincerely desire to renounce the devil and all his works, then declare it before God and this congregation.

In response to this statement, candidates may say, Ânâ da yi, mepa Jbonsam no, ne ayônkofa biara a âda me ne no ntam. Me gyaw abrabs dedaw a m'anfa me ho anto Otumfos Nyankopsn so, na mom, me de me ho too atumi

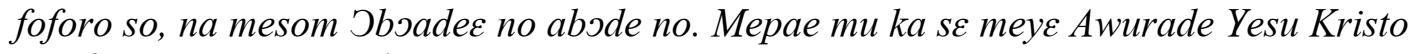
somfo. Meson no me nkwa nna nyinaa.

This day, I renounce the devil and every relationship that exists between him and me. I leave the old life in which I have trusted in powers other than the Almighty God and in which I have served created things rather than the Creator. I now enter the service of the Lord Jesus Christ and promise to serve Him all the days of my life.

The candidates may also have to remove from themselves any curses that may have come by their being associated with the Odosu. They have to declare their redemption from the curse achieved for them by Jesus' death on the cross. The PCG, and perhaps all the other churches in Ghana, may have to look again at their liturgy for baptism or even the "sinners' prayer" that is said at the point of conversion.

There have been several debates on what happens at the point of conversion and what does not, until a convert makes a personal verbal renunciation. The fact that such debates exist shows that there is an issue that is not easily resolved. The only way to be sure to benefit from the achievement of Christ for humankind is to "fulfil all righteousness",

\footnotetext{
62 Romans 7:15.

63 Ghana Presbyterian Asafo: Asôre Yâbea ne Mpae Ahorow, 94.

${ }^{64}$ Presbyterian Church of Ghana, Liturgy and Service Book, (Accra: Waterville Publishing House, 1987), 123
} 
and leave no space for doubting - accept Jesus Christ as Lord and Saviour, and consciously verbally renounce any association with Satan through any covenants, remove all curses that have come with that association, and remove any consequences of breaking the covenant in the name of Jesus. In the light of this, Christian ministry among Akuapemfo must make space for the people to verbally renounce any existing covenant between them and the Odosu as well as any consequences that may follow their turning from it to Christ. This will ensure that Akuapem Christians will not keep wondering if situations they face after becoming Christians are not due to the covenant that Okuapeman has with the Odosu.

\section{CONCLUSION}

From the foregoing, it has been established that the Okuapehene Dwira is a covenant renewing festival. Okuapeman has a covenant with the $O d o s u$ which is renewed annually through the celebration of the festival. Since the festival is officiated by the Okuapehene, he renews it on behalf of all Akuapemfo. This means that every Okuapeni is included in the covenant. When Akuapemfo become Christians, they move out of the covenant. There is the possibility of the consequences of breaking the covenant coming upon the converts as some Christians claim. To be sure that converts to Christ who are Akuapemfo are liberated from the covenant and its consequences, ministers of the church must give the converts the opportunity to renounce the covenant and its consequences. This must be done with those who are now becoming Christians. Those who are already Christians but have not had the opportunity to make this conscious renunciation, must also be given the opportunity to do so, if they wish. In this way, they can be sure that they have broken all contacts with the Odosu. They would not have to worry about the consequences of not joining in the renewing of the covenant. The covenant is broken for these converts and all their descendants.

\section{BIBLIOGRAPHY}

Akyempo, Karikari, Aboakyer:Deer Hunt Festival of the Effutus, (Accra: Anowuo Educational Publishers, undated). Asihene, E. V. Apoo Festival, (Tema: Ghana Publishing Corporation, 1980).

Bannerman, J. Yedu, et al, Mfantse Nkasafua na Kasambirenkyi Nkyerâase, (Tema: CEFIKS, 2011).

Birikorang, Nana Addo, "Akuapem Odwira - Adaebutuw Festival", Akuapem Odwira and Adae Butuw Festivals Odwira Souvenir Brochure, 1998.

Brokensha, David, Akwapim Handbook, (Accra-Tema: Ghana Publishing Corp, 1972).

Bruce, F. F., The Gospel of John, Introduction, Exposition and Notes, (Grand Rapids, Michigan: William B Eerdmans Publishing Company, 1983).

Busia, K. A. Busia, "The Ashanti," in Daryll Forde, African Worlds: Studies in the Cosmological Ideas and Social Values of African Peoples, (London: Oxford University Press, 1954,1970).

Carson, H. M., The Epistles of Paul to the Colossians and Philemon, (Leicester, England: Inter-Varsity Press, 1984).

Conner, Kevin, and Malmin, Ken, The Covenants, (Portland, Oregon: City Bible Publishing, 1997).

Daunton-Fear, Andrew, "Deliverance and Exorcism in the Early Church", in Kay and Parry (Eds), Exorcism and Deliverance

Field, M. J., Religion and Medicine of the Ga People, (Accra: Presbyterian Book Depot, 1961).

Ghartey, John B., Marriage Means More: Pragmatic Positive Principles for Building a Happy Home, (Accra: Living Word Foundation, 2009).

Gilbert, Michelle, "Aesthetic Strategies: The Politics of a Royal Ritual, Africa: Journal of the Internal African Institute, 64, no.1, (1994), 99 - 125.

Hammond, F. \& I., Pigs in the Parlour: A Practical Guide to Deliverance, (Kirkwood: Impact Books, 1973).

Hare, Douglas R. A., Interpretation: A Bible Commentary for Teaching and Preaching, Matthew, (Louisville, Kentucky: Westminster John Knox Press, 1993).

Harris, Murray J., Colossians and Philemon, (Grand Rapids, Michigan: William Eerdmans Publishing Company, 1991). Hickey, Marilyn, Breaking the Generation Curse, (Denver: Marilyn Hickey's Ministry, 1988).

Kalu, Ogbu U., The Embattled Gods: Christianization of Igboland 1841-1991, (Lagos: Minaj Publishers, 1996).

Kasdorf, Hans, Christian Conversion in Context, (Scottdale, Pennsylvania: Herald Press, 1980).

Kwamena-Poh, M. A., "History", David Brokensha, Akuapem Handbook, (Accra-Tema: Ghana Publishing Corporation, 1972).

Mac Nutt, Francis, Deliverance from Evil Spirit: APractical Manual, (London: Hodder \& Stoughton, 1995).

McAll, R. Kenneth, Healing the Family Tree, (London: Sheldon Press, 1997).

McDonald, H. Dermot, Commentary on Colossians and Philemon, (Waco, Texas: Word Books, 1980). 
Meyer, Birgit, Translating the Devil: Religion and Modernity among the Ewe in Ghana, (Edinburgh: Edinburgh University Press, 1999).

Onyinah, Opoku, Pentecostal Exorcism: Witchcraft and Demonology in Ghana, (Blandford Forum: Deo Publishers, 2012).

Prince, Derek, From Curse to Blessing: A Transcription of the Radio Program Today with Derek Prince, (Lauderdale: Derek Prince Ministries, 1986).

Rattray, R. S., Ashanti, (Oxford: Claredon Press, 1927).

Sarpong, Peter, The Sacred Stools of the Akan, (Accra-Tema: Ghana Publishing Corp, 1971)Smith, Noel, "The Churches", in David Brokensha (Ed.) Akwapim Handbook Strong, James, Strong's Concordance (A Concise Dictionary of the Words in the Hebrew Bible with their Renderings in the King James Version), (Nashville: Abingdon Press, 1986).

Walls, Andrew F., Cross Cultural Studies in Mission History, (Maryknoll, New York: Orbis Books, 1996).

"Christian Witness to People of African Traditional Religions," (LOP 18) - Lausanne Movement. Report of the consultation on World Evangelization Mini-Consultation on Reaching Traditional Religionists (Africa) held in Pattaya, Thailand from 16 - 27 June 1980 sponsored by Lausanne Committee for World Evangelization. Accessed April 1, 2020, http://www.lausanne.org/content/lop/lop-18. 